\author{
GRAŻYNA ZARZYCKA \\ (D) https://orcid.org/0000-003-2458-1228 \\ Uniwersytet $Ł o ́ d z k i$ \\ Łódź
}

\title{
Mechanizmy interkulturowych zdarzeń komunikacyjnych, w których dochodzi do zagrożenia twarzy
}

\author{
Mechanisms of face-threatening intercultural communicative events
}

\begin{abstract}
The paper presents a fragment of the author's research into interferences in intercultural communication with the participation of foreign students learning Polish. The research made it possible to record various stressful situations and stressogenic factors, including "face-threatening" ones, namely those involving the risk of losing one's face, to which the foreign interlocutor, or sometimes also the other participant of the communication act, were exposed. The aim of the research is to detect mechanisms causing the image of the interlocutor or interlocutors to be upset (undermined). It also identifies and discusses didactic and non-didactic situations causing negative emotional perceptions and mental states at least in one of the communicating parties. The paper uses the concepts of "face" by E. Goffman, P. Brown and Levinson, as well as conceptual apparatus and research methodology of American communication ethnographers.
\end{abstract}

Key words: mechanisms, communication events, face-threatening act, image, intercultural communication

\section{Wprowadzenie}

- objaśnienie kluczowych terminów oraz celów badawczych

Za interkulturowe zdarzenie komunikacyjne uznaję epizod, w którym dochodzi do spotkania osób różniących się od siebie pod względem kulturowym - jest to więc spotkanie Innych. W tego rodzaju interakcjach często dochodzi do zakłóceń spowodowanych różnorodnymi czynnikami - m.in. brakiem wspólnej płaszczyzny komunikacyjnej, niepełną wiedzą rozmów- 
ców o sobie, zachowaniem nieodpowiednim w danej sytuacji (z punktu widzenia którejś ze stron), odmiennymi sposobami interpretowania ważnych dla rozmówców spraw, innym kodem zachowań społecznych.

Akt, w którym dochodzi do zagrożenia twarzy, pojmuje jako zdarzenie komunikacyjne, wywołujące negatywny efekt emocjonalny któregoś z jego uczestników, wyrażające się (poczynając od najłagodniejszego efektu psychicznego do najsilniej odczuwanego) poczuciem: niepewności, braku kontroli nad sytuacją, zażenowania bądź nawet wstydu i upokorzenia. Dochodzi wtedy do naruszenia podstaw, na których w danym momencie zbudowany był czyjś wizerunek własny, czyjaś tożsamość, czyjeś poczucie godności. Jest to więc takie zdarzenie, które podaje w wątpliwość dotychczasowy wizerunek uczestnika interakcji, powodując jego rozchwianie.

Akty zagrażające twarzy wywołują często efekt wtórny o charakterze obronnym w postaci oburzenia, gniewu, wybuchu złości osób, które poczuły się w danej sytuacji niepewne lub urażone. Niekiedy możemy obserwować bardziej wyważone reakcje na akty zagrożenia (rzeczywistego bądź antycypowanego) własnego wizerunku. Osoby poddane działaniom czynników stresujących, a niekiedy też druga strona komunikacji, obmyślają więc różnorodne sposoby pozwalające im „wyjść z twarzą" z trudnej sytuacji. Jednym $z$ nich jest negocjowanie $z$ druga stroną komunikacji warunków, które pozwola zachować dotychczasowy status, czyli „zachować twarz”.

Pojęcie „twarzy” pojmowanej jako wizerunek - społeczny obraz - osoby zostało wprowadzone i zdefiniowane przez Ervinga Goffmana (ang. 1967; wyd. pol. 2006, 12)1 , a koncepcja zagrożenia twarzy pozytywnej i negatywnej rozpowszechniona przez Penelopę Brown i Stephena C. Levinsona (1987) w ich modelu grzeczności². Te i kolejne koncepcje grzeczności zostały

1 W książce Rytuat interakcyjny E. Goffman $(2006,12)$ pisze: „Twarz jest obrazem własnego ja naszkicowanym w kategoriach uznanych atrybutów społecznych”. Autor podkreśla, że twarz może być obrazem zbiorowym bądź indywidualnym wyobrażeniem o sobie samym. Zachowanie twarzy Goffman wiąże z działaniami zgodnymi z przypisaną komuś rolą społeczną, a jej utratę z wypadnięciem z przypisanej komuś lub sobie społecznej roli.

2 Zgodnie z teorią grzeczności Brown i Levinsona (1987), uznawanej dziś za klasyczną teorię grzeczności językowej, w aktach komunikacji zagrażających twarzy rozmówcy lub słuchacza (face-threatening acts) może dochodzić do sytuacji, w których: a) rozmówca ma wrażenie, że nie jest szanowany i traktowany z respektem (np. gdy się go krytykuje, zawstydza, oskarża o coś itp.) - dochodzi wtedy, zdaniem autorów, do zagrożenia jego „twarzy pozytywnej”; b) podważana jest jego wolność osobista, autonomia rozmówcy lub słuchacza (np. gdy ktoś mu coś rozkazuje, poleca, gdy czegoś mu zabrania, gdy coś na nim wymusza); dochodzi wtedy do zagrożenia jego „twarzy negatywnej”. 
omówione w krajowej literaturze m.in. w pracach Małgorzaty Marcjanik (2008, 11-26), Anny Żurek (2008), Emilii Sztabnickiej (2017, 10-27)3. Wiele pragmalingwistycznych analiz grzeczności „naszej” i „obcej” znajdujemy ponadto w pracach zbiorowych pod red. M. Marcjanik (2005, 2007).

W niniejszym artykule przeanalizuję zdarzenia komunikacyjne z udziałem cudzoziemców uczących się języka polskiego jako obcego (JPJO), opisywane z ich perspektywy oraz z punktu widzenia nauczyciela JPJO, który - w pewnych przedstawianych tu przykładach - był jedną z komunikujących się stron, a w innych obserwatorem zdarzenia lub osoba, której owo zdarzenie zostało zrelacjonowane. Poddane analizie epizody pochodzą $z$ archiwum badań własnych autorki. Niektóre z przedstawianych dalej przykładów były wcześniej opisane w dzienniku zdarzeń komunikacyjnych, które prowadziłam na różnych etapach swojej kariery zawodowej wykładowczyni JPJO (od końca lat 80 . XX wieku do dziś). Inne zostały zebrane przeze mnie w formie narracji pozyskanych w latach 2008-2018 w wyniku badań ankietowych nad incydentami krytycznymi w życiu studentów zagranicznych (ich wstępny etap został przedstawiony w: Zarzycka 2010).

Przyjęłam rozumienie zdarzenia komunikacyjnego, jak też sugestie dotyczące sposobów badania komunikacji (zob. akronim pojęcia: SPEAKING) za etnografami komunikacji (Hymes 1994, Saville-Troike 1994). W artykule analizuję wybrane epizody, biorąc pod uwagę rodzaj sceny - miejsca, tła, kontekstu, w jakim dane zdarzenie komunikacyjne się rozgrywa oraz role społeczne uczestników zdarzeń. Interesują mnie mechanizmy zdarzeń powodujących rozchwianie wizerunku własnego rozmówców. Zastanawiam się więc, w jakich sytuacjach komunikacyjnych dochodzi do zagrożenia poczucia wartości uczestników zdarzeń oraz co wywołuje negatywne odczucia rozmówców: ich niepewność, wstyd, upokorzenie itd. W niektórych przypadkach opisywane są także strategie wyjścia z trudnej sytuacji, a więc próby (szczególnie te udane) ochrony wizerunku własnego, zmniejszania efektu zagrożenia twarzy.

\footnotetext{
3 Ta autorka w obronionej w 2017 r. na UŁ rozprawie doktorskiej pt. Model polskiej grzecznośi jezykowej w nauczaniu jezyka polskiego jako obcego. Perspektywa interkulturowa (Sztabnicka-Gradowska 2017, 18-21) omawia także szczegółowo koncepcje postmodernistyczne i dyskursywne, rozwijające koncepcję Brown i Levinsona lub krytyczne wobec niej. Przykładowo według Naomi Geyer (2008, 57; za: Sztabnicka-Gradowska 2017, 21) twarz to „pozytywny obraz samego siebie tworzony w dyskursie", a więc każdorazowo w interakcji. Jest to, jak się wydaje, podejście bliskie fenomenologicznej koncepcji „tożsamości w podróży” (Mamzer 2003), przyjmowanej także przez niektórych pedagogów interkulturowych.
} 


\section{Analiza wybranych zdarzeń komunikacyjnych}

Wśród przykładowych zdarzeń komunikacyjnych poddanych oglądowi w niniejszym studium są:

1) takie, które miały miejsce w przestrzeni uczelni krajowej lub zagranicznej: a) w klasie - podczas kursu JPJO lub podczas innej sytuacji dydaktycznej z udziałem cudzoziemców lub b) poza klasą, np. podczas przerwy, w akademiku, w stołówce uczelnianej;

2) takie, których tłem była przestrzeń zewnętrzna, pozadydaktyczna, eksplorowana samodzielnie przez cudzoziemców uczących się JPJO; przeanalizowano tylko takie przykłady, które zostały bezpośrednio zrelacjonowane przez uczestników zdarzeń.

Przykładowe akty komunikacyjne zostały uporządkowane ze względu na rodzaj sytuacji, w której pojawia się konkretny mechanizm wywołujący zagrożenie twarzy uczestnika (lub uczestników) aktu komunikacyjnego.

Zdarzenia komunikacyjne mające miejsce w uczelni: podczas kursów JPJO (w klasie) oraz w przestrzeni niedydaktycznej (poza klasą)

W poniższym wykazie ukazane są rzeczywiste sytuacje, w których doszło do zagrożenia twarzy cudzoziemca uczącego się języka polskiego, nauczyciela JPJO lub obu komunikujących się stron ${ }^{4}$.

Gdy na lekcji nauczyciel używa języka, którego uczący się nie zna, zagraża twarzy tego uczącego się - powoduje, że czuje się on pokrzywdzony, gorszy od studentów, którzy mają wspólny język z lektorem.

Przykłady: Zanotowałam w mojej pracy przypadki głośnych reprymend studentów nieznających języka pośredniego skierowanych do mnie w takiej sytuacji: (Irakijczyk:) *,Ty mów po polsku, nie po angielsku”; podobnie jedna ze studentek z Chin: *,To lekcja polski, nie angielski”.

Tego rodzaju zachowania studentów były typowe raczej dla kursów JPJO odbywających się w wieku XX, kiedy nie wszyscy studenci znali język angielski. Zapamiętałam te incydenty i nawet dziś, w czasach globalnej znajomości

${ }^{4}$ Niektóre z przykładów zostały wcześniej przedstawione w: Zarzycka 2000. 
angielszczyzny, staram się jak najszybciej, już w 7-8 tygodniu zajęć JPJO dla początkujących, prowadzić je wyłącznie w języku docelowym.

Wyróżnianie przez nauczyciela kogoś z grupy studenckiej lub działanie nauczyciela niezgodnie z kodem zachowania akceptowanym przez uczącego się może wywołać jego zagrożenie twarzy, a czasem też ostrą krytykę zachowania nauczyciela.

Niektóre reakcje uczących się mogą być uwarunkowane względami politycznymi, których nauczyciel prowadzący zajęcia w danym momencie sobie nie uświadamia. Jawnie wyrażone podczas lekcji oburzenie studenta - czyli zachowanie niezgodne z przyjętymi na lekcji zasadami grzeczności - powoduje również zagrożenie twarzy uczącego, podważenie jego nadrzędnego statusu.

Przykład: Kurd pouczył lektorkę, która - jego zdaniem - była zbyt łagodna dla studentów arabskich zachowujących się nagannie: *,Ty bądź strong do oni”. Kurd poczuł się urażony, że nauczycielka zachowuje się zbyt przyjaźnie wobec studentów arabskich, których on uważał za wrogów. Lektorka, nieprzyzwyczajona do tak otwartej krytyki ze strony uczącego się, poczuła się urażona zachowaniem studenta, a także tym, że doszło tu do nadszarpnięcia jej wizerunku.

Przykład: Student z Chińskiej Republiki Ludowej (ChRL) wywołał awanturę na lekcji języka polskiego w chwili, gdy lektorka użyła określeń: „Tajwan”, „Tajwańczyk”. Jeden z uczących się w wielonarodowościowej grupie studenckiej był mieszkańcem Republiki Chińskiej (urzędowa nazwa państwa położonego na wyspie Tajwan), ale uważał siebie za Tajwańczyka. Student z ChRL był wzburzony i powiedział, że takie państwo jak Tajwan nie istnieje (odczuł zachowanie lektorki jako zniewagę wobec swojego kraju). Lektorka poczuła się równie oburzona z powodu zachowania studenta z ChRL - podobnie jak w poprzednim przykładzie, został zagrożony jej wizerunek jako wykładowczyni. Lektorka poprosiła o interwencję w tej sprawie osobę nadrzędną (dyrektora instytucji), która doprowadziła do spotkania niezadowolonego studenta z Chin z pośrednikiem - innym studentem z Chin kontynentalnych, który od wielu lat przebywał w Polsce i uczył się w SJPdC UŁ na którymś z kolei kursie. Jego zadaniem było przekonanie rodaka $z$ krótszym stażem pobytu w Polsce, że jeśli ktoś czuje się Tajwańczykiem (lub przedstawicielem innej wspólnoty) to w naszym kraju przyjmuje się jego punkt widzenia i określa się go zgodnie z jego poczuciem tożsamości. Nie powinien obarczać lektorki winą, ani wywoływać awantury politycznej na lekcji. 
Zagrożenie twarzy uczących się może być spowodowane ich obawą przed ośmieszeniem się przed grupą w sytuacji „występu na forum” i/lub zbyt krytyczną samooceną działań podjętych w języku docelowym.

Przykład: Profesor amerykańskiej uczelni (ekonomista) uczestniczył w moim kursie języka polskiego w DePaul University w Chicago - przygotowywał się do wyjazdu zawodowego do Polski, biorąc udział w zajęciach wraz z dużo młodszymi studentami. Traktowałam go początkowo tak, jak innych słuchaczy, a więc pytałam i wywoływałam do odpowiedzi. Radził sobie nieco gorzej niż inni. Po drugich zajęciach poprosił, bym go pytała tylko wtedy, kiedy sam się zgłosi. Zgodziłam się i od tego momentu byliśmy świadkami jedynie właściwych odpowiedzi uczącego się polszczyzny profesora. Odczuwał on uczestnictwo w lektoracie języka polskiego jako rywalizację z młodszymi studentami (z osobami o niższym statusie). Obmyślił więc sposób na to, by jego wyższy status nie został obniżony w sytuacji uczestnictwa w zajęciach uczelnianych ${ }^{5}$. Wynegocjowana z lektorką strategia unikania sytuacji zagrażającej utracie twarzy okazała się skuteczna.

Przykład: Niemka, uczestniczka kursu adaptacyjnego dla słuchaczy programu Erasmus w U⿺ na poziomie średnio zaawansowanym, podeszła do mnie po zajęciach i stwierdziła, że wszyscy studenci są na wyższym od niej poziomie językowym, w związku z czym ona ma wrażenie, że odstaje od grupy (było to tylko jej subiektywne odczucie). Na pytanie, jak chciałaby zaradzić tej sytuacji, odpowiedziała, że prosi mnie, bym w przeddzień każdych zajęć udostępniała jej materiały dydaktyczne (teksty, zadania), żeby się mogła wcześniej przygotować do lekcji. Zaakceptowałam tę, niezbyt wygodną dla mnie, propozycję; studentka z Niemiec do końca kursu językowego nie powróciła już do tego tematu6.

Przykład: Zaprosiłam uzdolnionego językowo, pochodzącego z Tajpej, studenta dziennikarstwa na Wydziale Filologicznym UŁ, żeby przyszedł

5 Status społeczny to czynnik w bardzo dużym stopniu modelujący komunikację międzyludzka, w tym relacje interkulturowe; zob. pracę Siedem wymiarów kultury F. Trompenaarsa i Ch. Hampdena-Turnera (2002, rozdz. 8, 126-144), w której status (osiagnięty i przypisany) został uznany za istotny wymiar różnicujący kultury.

${ }^{6}$ Opisaną w tym przykładzie sytuację można z kolei odnieść do wymiaru kultury określonego przez G. Hofstedego jako unikanie niepewności (zob. Hofstede, Hofstede, 2007, 177219.). Skrupulatne planowanie działań jest jedną ze strategii pomagających uniknąć sytuacji, w tym tych mających miejsce w pracy czy w szkole, które mogą kogoś zaskoczyć i zaniepokoić. Z moich doświadczeń wynika, że osoby uczące się JPJO pochodzące z Niemiec lubią się uczyć w środowisku, nad którym mają kontrolę. 
jako gość na mój ogólnouczelniany wykład o wyzwaniach komunikacji interkulturowej. Student przedstawił po polsku prezentację o swoim kraju i odpowiedział na pytania uczestników wykładu. Jednak, mimo że poradził sobie pod względem językowym bardzo dobrze, a reakcja słuchaczy na jego wystapienie była pozytywna, był z siebie bardzo niezadowolony $\mathrm{z}$ powodu popełnianych $\mathrm{w}$ czasie wystapienia prostych błędów gramatycznych: „Byłem beznadziejny!’”.

Gdy nauczyciel nie spełnia obietnicy, zachowuje się niezgodnie $z$ akceptowanymi przez studenta zasadami grzeczności, nie chwali uczącego się (wtedy, gdy on tego oczekuje), nie jest dość empatyczny ${ }^{8}$, pomija lub lekceważy uczącego się lub zapomina o czymś dla niego ważnym, może to być powodem poczucia niedowartościowania uczącego się.

Przykłady: Lektorka obiecała wyjście do zoo ze studentkami, a nie poszła. Studentka z Białorusi była tym faktem tak rozczarowana, że przedstawiła go w ankiecie jako najtrudniejszą sytuację, której doświadczyła podczas pierwszego roku swojego pobytu w Polsce.

Student z dawnej Jugosławii odczuł jako ujmę na honorze to, że ani lektorka, ani grupa studencka nie pamiętali o jego święcie narodowym; głośno skarcił za to nauczycielkę i kolegów z grupy.

Jedna ze studentek z Palestyny obraziła się na nauczycielkę, gdy ta jej nie pochwaliła na forum grupy.

Studenci jednej z grup studenckich napisali skargę na lektorkę, gdy ta określiła ich (mrucząc pod nosem tak, by jej nie usłyszeli) jako głupich.

Oskarżanie niewinnej osoby o czyn niegodziwy, zmuszanie kogoś do działania niezgodnego z jej normami etycznymi upokarza tak potraktowaną osobę; powoduje znaczny uszczerbek jej godności osobistej, szczególnie wtedy, gdy inicjatorem takiego represyjnego działania jest ktoś, kogo się nie poważa lub nie darzy sympatią.

7 Zob. wnikliwy artykuł N. Tsai (2015) o percepcji własnych błędów przez uczących się angielskiego, oparty na badaniach własnych autorki przeprowadzonych w wyższych uczelniach w Tajpej. Wynika z nich, że duża grupa jej studentów (82\% badanych) opisała negatywne reakcje (jak: zdenerwowanie, wstyd przed ośmieszeniem się przed kolegami lub nauczycielem, niepewność, zwiększenie nieśmiałości) na popełniane przez siebie błędy na lekcji języka angielskiego.

${ }^{8}$ Empatia jako sketadowa mediacji kulturowej to jeden z projektów międzynarodowych opisanych w monografii Cultural Mediation in Language Learning and Teaching (Zarate, Gohard-Radenkovic, Lussier, Penz, 2004). Celem projektu było wychwycenie przykładów i typów zachowań empatycznych i nieempatycznych podczas interakcji nauczyciela z uczącymi się języka obcego. Wyniki badań tego zespołu projektowego opisałam w: Zarzycka $(2018,125)$. 
Przykład: Gdy studentowi z Afryki zginął portfel, jego właściciel zarządził zamknięcie sali lekcyjnej i przeszukanie wszystkich zgromadzonych w klasie. Wzburzona studentka z Iraku kolejnego dnia przyszła do lektorki i poprosiła o przeniesienie do innej grupy: „Jak on mnie potraktował! Ja jestem arabską kobieta!"' Nastąiło tu zagrożenie tzw. twarzy negatywnej Irakijki - poczucia jej wolności osobistej. Podważono jej godność - dla arabskiej kobiety posądzenie o kradzież stało się wielką ujmą na honorze. Irakijka była tym bardziej wzburzona, że inicjatorem owego działania był Afrykańczyk, którego z ledwością tolerowała.

Zróżnicowany poziom wiedzy ogólnej rozmówców (np. z zakresu geografii, historii czy politologii) lub odmienny sposób interpretowania "wrażliwych danych" może wywołać efekt zagrożenia twarzy któregoś z rozmówców.

Przykład (podany przez studenta z Rosji): „Spytałem kiedyś mieszkającego obok mnie Araba o to, skąd przyjechał do Polski. Odpowiedź brzmiała następująco: »Przyjechałem z Palestyny«. To mnie zainteresowało, ponieważ wiem, że oficjalnie Palestyna nie istnieje, ale myślałem, że mieszka na przykład na Zachodnim Brzegu Jordanu. Dlatego spytałem jeszcze, jak daleko on mieszka od Izraela. $\mathrm{Na}$ te słowa zareagował w sposób bardzo emocjonalny i rzekł, że nie zna takiego państwa jak Izrael (poza tym byl bardzo oburzony i niezadowolony). W taki s posób powstała trudna sytuacja, z której jako wyjście posłużyło ustalenie położenia geograficznego miasta tego Araba w stosunku do Jerozolimy."

W początkowej fazie tego zdarzenia została zagrożona twarz Palestyńczyka, występującego w tym epizodzie jako przedstawiciel i obrońca określonej wspólnoty narodowej. Wysoce skuteczna okazała się zastosowana przez rozmówcę z Rosji zmiana perspektywy (zob. podkreślony fragment), co spowodowało rozwiązanie trudnej sytuacji komunikacyjnej.

Dowcip, żart, może być niezrozumiany lub zrozumiany opacznie, niezgodnie z intencją nadawcy, co może powodować dyskomfort psychiczny odbiorcy bądź nawet przerwanie aktu komunikacyjnego.

Przykład: W czasie przerwy Palestyńczyk zwraca się do lektorki: - Daj, pani, pieniądze, bo chcę kupić kwiaty na Dzień Kobiet.

Lektorka (zdenerwowana): - Ja nie chcę kwiatów.

Inny student palestyński: - On żartuje. W Palestynie kobiety nigdy nie płaca. 
Lektorka: - W Polsce czasami płaca.

Doszło tu do zagrożenia twarzy lektorki, która poczuła się obrażona niezgodnym z normami grzecznościowymi poleceniem pierwszego ze studentów. Sytuację załagodził drugi student, który w tym zdarzeniu odegrał rolę mediatora kulturowego.

Przykład: Student arabski do Afrykańczyka (kpiąco, gdy roztargniony Afrykańczyk nie potrafi odpowiedzieć na pytania nauczyciela): - Mamadou, masz głowę?

Mamadou (obrażony i zdenerwowany): - *Mam dwa głowy.

Podobny efekt wzburzenia mogą wywołać lapsusy językowe, a nawet użycie określonych obcojęzycznych struktur językowych, jeśli ze względów kulturowych dotykają one ego uczestnika zdarzenia komunikacyjnego.

Przykład: Irańczyk Reza wyraża oburzenie i ucina kontakt ze swoim kolega z grupy, gdy ten omyłkowo nazywa go Reksem - imieniem psa z podręcznika (a w wielu krajach Azji nazywanie kogoś psem jest wyjątkowo obraźliwe, bardziej nawet niż w Polsce).

Przykład: Studenci, szczególnie arabscy, reagują w początkowym etapie nauki języka polskiego wzburzeniem na formy imion męskich zakończone w bierniku i dopełniaczu l.poj. na samogłoskę -a, np.: „pana, Kamala, Amina”, uznając, że ich użycie deprecjonuje ich męskość.: „Ja jestem pan/Kamal/Amin, nie: pana/Kamala/Amina!' Warto zauważyć, że na samogłoskę -a kończą się w języku arabskim warianty żeńskie tych imion. Podobnie reagowali na formę 'panie' w zwrocie bezpośrednim: „Panie Kamalu, Aminie”, odbierali ją wyłącznie jako mianownik l.mn. rzeczownika „pani”.

Przykład: Studentka z Iraku do dwudziestokilkuletniej lektorki: *„Czy do taka stara profesora ja mogę mówić ty"? Mimo że lektorka nie była w podeszłym wieku i rozumiała właściwy sens pytania, poczuła się w tej sytuacji zakłopotana i nieco urażona. Jeszcze większy dyskomfort czują osoby starsze - nauczyciele, pracownicy administracji - gdy cudzoziemcy nieświadomie łamią zasady savoire-vivre'u, używając wobec nich formy „ty” zamiast „pan”, „pani” lub gdy zachowują się obcesowo.

Efekt zakłopotania może również wywołać niestosownie użyty, np. w sytuacji prowadzenia przez lektorkę lekcji, komplement uczniowski. 
Zachowania niewerbalne niezgodne z kodeksem zachowań grzecznościowych obowiązującym w danej kulturze mogą powodować poczucie napięcia i nadszarpnięcie wizerunków stron danego aktu komunikacyjnego.

Przykład: Lektorka poczuła się nieswojo, gdy w stołówce przysiadła się do stolika dobrze jej znanego studenta z Palestyny, a ten poczęstował ją jedzeniem ze swojego talerza. Gdy odmówiła, student przestał się do niej odzywać. (W tej sytuacji zażenowani byli oboje uczestnicy zdarzenia).

\section{Zdarzenia, które miały miejsce poza uczelnią}

Badania ankietowe ujawniły kilkanaście typów trudnych sytuacji, jakich doświadczają cudzoziemcy w czasie pobytu w Polsce, gdy znajdują się poza „oswojoną” przestrzenią uczelni lub akademika (Zarzycka 2010). Poniżej przedstawiam przykłady incydentów, które w jaskrawy sposób wzburzyły cudzoziemców opisujących owe zdarzenia, wywołując w nich szok, poczucie dyshonoru, poniżenia, upokorzenia lub wstydu. Opisując tego rodzaju sytuacje i swoje położenie w czasie danego wydarzenia, często opatrywali je komentarzami oraz ilustratorami emocji takimi jak: „Było mi wstyd”, „Jaki skandal!”, „Byłem zawstydzony / byłam zawstydzona”, „To był dla mnie szok”, „Byłem zszokowany / byłam zszokowana”, Nie wiedziałem / nie wiedziałam, jak się zachować”, „To był najsmutniejszy dzień w moim życiu”, „Po raz pierwszy coś takiego przeżyłem/przeżyłam”, „Czułem się gorszy / czułam się gorsza” itp. Poniżej prezentuję wybór przykładów ${ }^{9}$ z uwzględnieniem psychofizycznego tła danego zdarzenia.

Znalezienie się w obcym kraju w roli uchodźcy wiąże się ze znacznym obniżeniem poczucia własnej godności.

Przykład: Student z Libii, opisując przylot do Polski (na lotnisku rozbito namioty, w których przez jakiś czas koczowali wygnańcy) po wybuchu wojny w 2006 r. w Libanie, napisał: „Na początku czułem się jakiś taki niechciany". Za najbardziej uciążliwą uznał niemożność znalezienia pracy przez ojca - lekarza specjalistę ze statusem uchodźcy.

Niekulturalne, pozbawione empatii zachowania urzędników paszportowych, sprzedawców, kontrolerów biletów czy pracowników służby zdrowia powodują dyskomfort psychiczny cudzoziemców, wywołując w nich odczucia gniewu, upokorzenia lub ostre reakcje związane z nierównym traktowaniem.

${ }^{9}$ Część z nich przedstawiłam wcześniej w: Zarzycka 2010. 
Przykłady: Białorusinka o sposobie przepytywania jej przez pracowników urzędu meldunkowego „Te pytania były okropne. Czułam się przesłuchiwana jak przestępca”.

Respondentka z Kazachstanu: „Nigdzie nie spotkałam takiego chamstwa ze strony ludzi, którzy mają władzę".

Kubanka o pracy recepcjonistów w szpitalu: „Mówią jak automaty. I nikogo nie obchodzi i nie interesuje, że jestem cudzoziemką i mam problemy z językiem”.

Białorusinka: „W szpitalach nie chcą przyjmować, jeżeli jest krytyczna sytuacja, tylko za miesiąc są terminy. Lekarze *niepilnie wykonują swoje obowiązki”.

Ukrainka: „Często odmawiano mi jako słuchaczce SJPdC pomocy zdrowotnej, odsyłano z jednego szpitala do drugiego".

Kubanka o niekulturalnym i świadczącym o braku kompetencji sposobie obsługi zagranicznego podróżnego na dworcu kolejowym w Warszawie: „Scena była skandaliczna! Cyrk! Kobieta zachowywała się tak, jakby cały świat musiał mówić po polsku”.

Koreańczyk przyłapany przez kontrolera w tramwaju bez ważnego biletu opisuje to jako „wielki skandal i wstyd”.

Stereotypizacja i uprzedzenia ujawniające się w zachowaniach Polaków powodują znaczny dyskomfort psychiczny rozmówców, destabilizują poczucie ich tożsamości, utrudniają aklimatyzację w Polsce.

Przykłady: Kazachstanka: „Niektórzy Polacy nie lubią, gdy mówię po rosyjsku lub po polsku z rosyjskim akcentem".

Ukrainka: „Gdy kontroler usłyszał, że jestem z Ukrainy powiedział: Tym bardziej muszę pani wypisać mandat”.

Ukrainka: „Usłyszałam od jednego chłopaka, jak mówił złośliwie o ukraińskich dziewczynach, że co druga dziewczyna na Ukrainie jest Tania. Tania to jest imię. Jednak on miał na myśli, że dziewczyny na Ukrainie są bardzo łatwe. To nieprawda, dlatego bardzo mnie to oburzyło".

Student z Ukrainy: „Było wiele takich sytuacji, kiedy to Polacy, kierując się stereotypami o Ukraińcach, odnosili się do mnie jak do gorszego". 
Studenci z Republiki Chińskiej: „Dlaczego urzędnicy pracujący w Uniwersytecie Lódzkim ciagle traktuja Tajwan jako Chiny? Przecież jest to niezależne państwo!?”; Palestyńczycy: „Dlaczego Polacy nie wiedzą, że jest taki kraj jak Palestyna?”. Również Kazachowie i Mongołowie denerwują się, gdy uważa się ich za Chińczyków.

Molestowanie seksualne i nagabywanie wywołuje u cudzoziemców niepewność, brak poczucia bezpieczeństwa, strach.

Przykłady: O seksualnym nagabywaniu słownym („Prześpijmy się!”, „Chodź ze mną do łóżka!”) i fizycznym (poklepywaniu, dotykaniu) przez młodych Polaków napisała studentka z Tajpej. Podobne zachowania ze strony nastoletnich chłopaków opisała Kazachstanka.

Greczynka: „Nie podobało mi się, jak pijani ludzie przyczepiali się do mnie lub do przyjaciółek i byli dość agresywni”.

Studenci z Turcji skarżyli się na nagabywanie młodych mężczyzn, często pijanych, o pieniądze, co wywoływało w nich strach.

Studentka z Mongolii opisała w ankiecie sytuację, w której ona i koleżanki zakwaterowane $\mathrm{w}$ hotelu robotniczym poza uczelnią (z powodu braku miejsc $\mathrm{w}$ remontowanym akademiku) były molestowane przez mieszkających tam mężczyzn pracujących na budowie: „Miałyśmy problem z wejściem do wspólnej kuchni, łazienki, bo widząc nas, zaczepiali, komentowali, pukali do drzwi, kiedy brałyśmy prysznic. W pewnym momencie nie wytrzymałyśmy, pokłóciłyśmy się z nimi i wyprowadziłyśmy się z hostelu".

Mowa nienawiści wyrażana w przestrzeni publicznej przez nieznajome osoby, środkami werbalnymi i niewerbalnie, wywołuje szok i przyczynia się w największym stopniu do poczucia osamotnienia i osaczenia cudzoziemców, szczególnie tych różniących się wizualnie od Polaków.

Przykłady: Turek: „Pewien pijak zapytał mnie, skąd jestem. Kiedy powiedziałem, że z Turcji, on powiedział, ze chce zabić wszystkich ludzi z Turcji”.

Albańczyk: „Tu w Polsce ludzie patrzą na mnie tak, jakbym nie był człowiekiem tylko dlatego, że rozmawiam w swoim języku z kolegami. Czasami słyszę od nich: »Nie dotykaj mnie!«, »Nie zbliżaj się do mnie!«. W Studium jest wszystko w porządku, ale poza szkołą ludzie nie są tacy przyjemni!”. 
Respondentka z Kamerunu opisała szokujący dla niej akt agresji słownej i fizycznej (polegający na popchnięciu jej kolegi i napluciu mu w twarz przez „Polaka z tramwaju”).

Turczynka: „W autobusie jakaś kobieta kazała mi wstać, popchnęła mnie".

Turczynka: „Najtrudniejszą sytuację miałam w autobusie. Jakaś kobieta chciała ode mnie pieniądze. [Kiedy jej nie dałam], podeszła do mnie, krzyczała i mówiła złe słowa. Potem podeszła do mnie i napluła mi w twarz. To było dla mnie straszne, byłam zszokowana. Inni ludzie, widząc to, nie reagowali”"

Turczynka: „Jeden starszy mężczyzna w autobusie miał laskę i mnie uderzył. Coś mówił, ale nie zrozumiałam. Był agresywny".

Angolanka: „W lutym, kiedy spacerowałam z inną koleżanką Angolanką po Piotrkowskiej, 2 dziewczyny i 2 chłopaków mówili do nas bardzo źle: 'małpa', 'czarnuch'. To jest dyskryminacja'.

Kongijczyk: „W Polsce zawsze mamy trudne sytuacje. Nie rozumiem, czy to rasizm, czy arogancja (bo nigdy nie widzieli osoby, która ma ciemną skórę)? Ostatnia taka sytuacja była, kiedy byłem w Gdańsku i jedno dziecko mówiło do mnie 'czarna małpa'. Podobne sytuacje mam na ulicy, w klubie, na dworcu. (...) Chcę wiedzieć, dlaczego oni *nie widzą Afrykańczyków jak ludzi, ale jak zwierzęta”.

"Zagrożenie twarzy" może być spowodowane dezorientacją o charakterze fizycznym (nieumiejętnością poruszania się w nieznanej przestrzeni miejskiej lub pozamiejskiej), nieznajomością języka polskiego oraz brakiem rozeznania w zakresie rozpoznawania wzorów kulturowych obowiązujących w danym środowisku.

Przykłady: Studentka z Estonii: „Nie wiesz, gdzie się co znajduje, nie wiesz, czym masz jechać, jak dojechać, gdzie masz jechać, nie wiesz gdzie masz chodzić, a gdzie niebezpiecznie".

Turczynka: ,Język jest tak niepodobny do tureckiego i tak dla mnie trudny, że nie wiem, co mam dalej robić".

Koreańczyk: „Przede mną jest ściana języka obcego”.

Angolanka: „Najtrudniejszą sytuacja jest język”. 
Gabriela (Rumunka, osoba wierząca, wyznawczyni prawosławia) opowiedziała kolegom i lektorce o tym, jak bardzo zestresował ja udział w mszy w obrządku katolickim:

„(...) Miałam taki szok, bo tam nie był chleb, wino, bo on czeka, aż wszyscy dają pieniądze. (...) Tak mi było źle, zażenowana byłam, nie miałam pieniądze. (...) On czeka na mnie. Ale potem zmieniłam miejsce i mu dałam. I dalej, i dalej msza szła. (...) Kiedy ksiądz coś mówił, oni też coś mówili, ja nie mogłam zrozumieć. (...) Co ja teraz zrobię? Nic nie mówię. W tym momencie musiałam mówić $(\ldots)^{10 "}$.

Podkreślono fragmenty ilustrujące odczucia narratorki związane z obawą o utratę wizerunku.

\section{Podsumowanie}

Przeanalizowane w niniejszej pracy przykłady interkulturowych zdarzeń komunikacyjnych ujawniły różnorodne mechanizmy, w których uczestnicy danego aktu komunikacji odczuwali negatywne emocje wpływające na obniżenie poczucia własnej wartości.

Część opisanych zdarzeń, a więc tych, których kontekstem było miejsce znane rozmówcom - klasa, akademik - nie różni się, jak sądzę, od tych, które mogą zaistnieć w środowisku jednokulturowym. Odczuwanie przez uczącego się niepokoju podczas wystąpienia przed grupą rówieśniczą czy na innym forum publicznym, poczucie wzburzenia, gdy się zostanie pominiętym lub niesprawiedliwie potraktowanym przez nauczyciela, można uznać za zjawiska typowe, uniwersalne. Zbytni samokrytycyzm może, oczywiście, wynikać z wychowania (w krajach azjatyckich znacznie bardziej restrykcyjnego i ukierunkowanego na bycie perfekcyjnym niż w krajach Europy Zachodniej).

W wielokulturowym środowisku szkolnym do aktów komunikacyjnych najbardziej zagrażających twarzy należy zaliczyć te, które wypływają z niskiej wrażliwości interkulturowej rówieśników i nauczyciela, z ich braku wiedzy ogólnej o normach zachowań obowiązujących w danym środowisku językowym i kulturowym, a często - z niskich (bądź nieprzystających do danej sy-

${ }^{10}$ Jest to fragment dłuższego transkryptu nagranej rozmowy odbywającej się w grupie studenckiej. 
tuacji) kompetencji dyskursywnych (werbalnych i niewerbalnych). Tego rodzaju niedostatki powoduja, że uczestnicy zdarzeń komunikacyjnych wywołują sytuacje powodujące zagrożenie ,ja” innych rozmówców. Do trudnych sytuacji należą te, w których podczas lekcji języka obcego, dochodzi w grupie rówieśniczej do konfrontacji różnych postaw politycznych czy etycznych oraz do zagrożenia czyjejś wolności osobistej. Jednak i tego rodzaju konflikty moga być zażegnane (choć niekiedy z trudem), gdy zostanie zastosowana odpowiednia strategia mediacyjna.

Bardzo ważną rolę w utrzymaniu w klasie swobodnej, pozbawionej napięcia, atmosfery w wielonarodowościowej grupie studenckiej spełnia nauczyciel: musi być osobą o wysokiej kulturze osobistej, empatyczna, sprawiedliwą, o rozwiniętych kompetencjach w zakresie mediacji kulturowej (a tego rodzaju kompetencje nie wypływaja jedynie z doświadczeń, ale także z ciągłego samokształcenia), a przede wszystkim powinien chcieć i umieć uczyć się na własnych błędach, bo tych nie uda mu się uniknacc. Jednym słowem, musi być wzorem osobowym dla swoich podopiecznych; to od niego będa się uczyć właściwych w danym środowisku kulturowym zachowań (począwszy od zwrotów grzecznościowych i odpowiedniego stosowania form adresatywnych „pan” czy „pani”). Podczas lekcji języka obcego, szczególnie gdy jest ona prowadzona w środowisku, które uczący się dopiero rozpoznaje, to właśnie lektor (w dużo większym stopniu niż Wikipedia czy inne źródła internetowe) jest dla uczącego się „otwartą książką”, przewodnikiem po kulturze języka docelowego.

Aktami komunikacyjnymi powodującymi największy dyskomfort cudzoziemców są niewątpliwie takie, których efektem jest odczucie pogardy, zniewolenia, bezsilności, wstydu i upokorzenia ${ }^{11}$. Tego rodzaju zdarzenia - miały miejsce w przestrzeni pozadydaktycznej, publicznej. Te najdotkliwiej odczute przez osoby je relacjonujące były konsekwencją mowy nienawiści, która przyjęła formę werbalną bądź niewerbalną, co wyrażało się niejednokrotnie naruszeniem nietykalności cielesnej. Takich zdarzeń jest w naszym kraju wiele. Wywołuja one strach przed poruszaniem się w przestrzeni publicznej u cudzoziemców wyglądających inaczej niż Polacy, a czasem jedynie używających języka innego niż polski.

$11 \mathrm{~W}$ artykule Utrata twarzy, czyli o upokorzeniu w aspekcie społecznym i jednostkonym M. Pachowicz $(2014,10)$ uznała, z czym się zgadzam, że „upokorzenie jest jednym z bardziej bolesnych i zaburzających naszą wewnętrzną równowagę. To negatywne uczucie wiąże się z naruszeniem godności człowieka, z poczuciem »utraty twarzy«". 
Studenci zagraniczni przyjeżdżający do Polski sa „pod ochroną” - dbają o nich opiekunowie grup studenckich, pracownicy administracyjni szkół wyższych, ale zmiana stosunku „zwykłych Polaków” (,prawdziwych Polaków”?) do Innych wymaga podjęcia wielowymiarowych działań skierowanych w stronę walki z mową nienawiści. Najważniejsze wydaje się wychowanie przyszłego pokolenia w duchu otwartości dla odmienności.

\section{Literatura}

Brown P., Levinson S.C., 1987, Politness. Some Universals in Language Usage, Cambridge. Hymes D., 1994, Foundation in Sociolinguistics. An Ethnographic Approach, Philadelphia. Geyer N., 2008, Discourse and Politness: Ambivalent Face in Japanese, Londyn.

Goffman E., 2006, Rytuat interakcyjny, Warszawa (ang. 1967, Interaction Ritual: Essays on Face-to-Face Behavior, Garden City NY, Doubleday).

Hofstede G., Hofstede G.J., 2007, Kultury i organizacje, Warszawa.

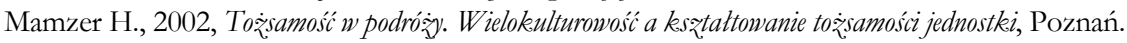

Marcjanik M., red., 2005, Grzeczzość nasza i obca, Warszawa.

Marcjanik M., red., 2007, Grzecz̨ość na krańcach śniata, Warszawa.

Marcjanik M., 2008, Grzecznośc w komunikacji jezylkowej, Warszawa.

Saville-Troike M., 1994, The Ethnography of Communication. An Introduction, Oxford.

Trompenaars F., Hampden-Turner C., 2002, Siedem wymiarón kultury. Znaçenie różnic kulturowych w driatalności gospodarczej, Kraków.

Tsai N., 2015, Taiwanese English learners' perceptions of errors in speaking, „Acta Universitatis Lodziensis. Kształcenie Polonistyczne Cudzoziemców”, nr 22.

Zarzycka G., 2000, Dialog miedryykulturowy. Teoria oraz opis komunikowania sie cudzoziemcón prayswajajacych jesyk polski, „Acta Universitatis Lodziensis. Kształcenie Polonistyczne Cudzoziemców", nr 11 (monografia).

Zarzycka G., 2010, Incydenty krytyczne, cayli najtrudniejsze dośniadcrenia stuchacsy Studium Jesylea Polskiego dla Cudzoziemcón UŁ, „Acta Universitatis Lodziensis. Kształcenie Polonistyczne Cudzoziemców", nr 17.

Zarzycka G., 2018, Mediacja kulturowa jako niedoceniony mymiar glottodydaktyki, w: Potasińska P., Stasieczek-Górna M., red., Wyzwania glottodydaktyki polonistycznej, Warszawa.

Żurek A., 2008, Teorie gržecżności jesy)kowej, „Kształcenie Językowe”, nr 7(17).

Pachowicz M., 2014, Utrata twary,y, cayli o upokorzeniu w aspekcie spotecznym i jednostkonym, „Parezja”, nr 2/2014.

Netografia

Sztabnicka-Gradowska E., 2017, Model polskiej grzeczności jesykowej w nauczaniu jesylka polskiego jako obcego. Perspeketywa interkulturowa (rozprawa doktorska), http://dspace.uni.lodz.pl:8080/ xmlui/bitstream/handle/11089/22939/ [dostęp: 10.05.2019]. 
Zarate G., Gohard-Radenkovic A., Lussier D., Penz H., 2004, Cultural Mediation in Language Learning and Teaching, Rada Europy, http://archive.ecml.at/documents/pub122E2004_Za rate.pdf [dostęp: 10.05.2019]. 